\title{
VOZES DA MATA. O MOVIMENTO SOCIAL QUILOMBOLA NAS MEMÓRIAS DE MULHERES DO RIO ANDIRÁ (2005-2018)
}

\author{
João Marinho da Rocha ${ }^{1}$
}

\section{Resumo}

Este texto aborda o movimento social quilombola do Rio Andirá (2005-2018), a partir das memórias de mulheres que estiveram envolvidas no processo de luta. Situamos nossa narrativa no campo da história social do pós-abolição e nos diálogos interdisciplinares entre história e ciências sociais, a partir de perspectivas metodológicas como história oral. Essa emergência étnica da história do tempo presente, implica, ações que nos convidam a (re)pensar os modelos teórico-metodológicos que explicam as presenças negras na Amazônia.

Palavras chaves: Memória; Mulheres Quilombolas; Andirá.

\begin{abstract}
This text addresses the quilombola social movement of the Andirá River (2005-2018), from the memory of women who were involved in the fighting process. We situate our narrative in the field of post-abolition social history and in interdisciplinary dialogues between history and social sciences, based on methodological perspectives such as oral history. This ethnic emergence of the history of the present time implies actions that invite us to (re)think of the theoretical-methodological models that explain the black presences in the Amazon.
\end{abstract}

Keywords: Memory. Maroon women. Andirá.

\footnotetext{
${ }^{1}$ Professor da Universidade do Estado do Amazonas, Centro de Estudos Superiores de Parintins, UEA/CESP.
} 


\section{Dos Cenários de Direitos e Lutas Quilombolas}

Em suas lutas por reconhecimentos como quilombolas comunidades de todo Brasil se articulam para acessar seus direitos indicados no âmbito da ressignificação do termo quilombo objeto do artigo 68 do Ato das Disposições Constitucionais TransitóriasADTC da Constituição Federal de 1988. Tal artigo confere direitos territoriais aos remanescentes de quilombo que estejam ocupando suas terras, sendo-lhes garantida a titulação definitiva pelo estado brasileiro ${ }^{2}$. "Ali se nomeava e se atribuía direitos a um heterogêneo conjunto de comunidades de predominância negra que, salvo raras exceções, não se pensavam em qualquer medida como 'remanescentes das comunidades de quilombos"3. Sua aprovação proporcionou uma "revisão histórica e mobilização política, que conjugava a afirmação de uma identidade negra no Brasil à difusão de uma memória da luta dos escravos contra a escravidão"4. Nesse contexto o termo "quilombo" deixa suas limitações históricas, a partir do modelo de Palmares, forjado no contexto da colonização, onde o conselho ultramarino o definiu como sendo "toda habitação de negros fugidos, que passassem de cinco, em parte despovoada, ainda que não tenha ranchos levantados e nem se achem pilões nele”. Esta ótica e definição influenciou a pesquisa histórica da temática quilombola até a década de 1970.

Dentro desse cenário de possibilidades e dispositivos legais é que foram encampadas lutas por todo país por reconhecimento das terras de "remanescentes" de quilombo. "Além da referência étnica e da posse coletiva da terra, também os conflitos fundiários vivenciados no presente aproximavam o conjunto das 'terras de preto', habilitando-as a reivindicar enquadrar-se no novo dispositivo legal" ${ }^{\text {. Sobre esses novos }}$ grupos étnicos "há situações históricas peculiares em que grupos sociais e povos percebem que há condições [...] para reconhecer suas identidades coletivas e mobilizar forças em torno delas e ainda para tornar seus saberes práticos um vigoroso instrumento jurídico-formal"6. Foi nesse contexto reivindicado socialmente que se abriram possibilidades para a busca dos direitos diferenciados de grupos étnicos-raciais criados

\footnotetext{
${ }^{2}$ O'DWYER, Eliane Cantarino. Os quilombos e as fronteiras da antropologia. Antropolítica. Niterói, n. 19, 2005, p.91-111.

${ }^{3}$ BRANDÃO, André; DALT, Salete da; GOUVEIA, Victor Hugo. Comunidades quilombolas no Brasil: características socioeconômicas, processos de etnogênese e políticas sociais. Niterói: EDUFF, 2010, p.78.

${ }^{4}$ MATTOS, Hebe. Cativeiro e Políticas de reparação no Brasil. Revista USP, São Paulo, n.68, dezembro/fevereiro 2005-2006; p.104-111, p.106.

${ }^{5}$ Idem

${ }^{6}$ ALMEIDA, Alfredo Wagner Berno de. Prefácio da primeira edição. In: ACEVEDO, Rosa ; CASTRO, Edna. Negros do Trombetas: Guardiões das matas e rios. Ed. Cejup/UFPA-NAEA, Belém, 1998, $2^{a}$ edição, p.17.
} 
na forja da história colonial, marginalizados e esquecidos na construção da nação e ressurgidos no contexto multiculturalista do final do século XX. Apresentando-se enorme desafio para historiadores, antropólogos e cientistas sociais engajados em torno da questão ${ }^{7}$. Compondo o cenário de possibilidades de busca por acessar direitos e (re)afirmação da identidade étnico-racial no Brasil.

Nos primeiros anos de implementação da Constituição Federal de 1988 os "quilombolas" colocaram as suas pautas de reivindicações, em meio a um ambiente de forte efervescência política e mobilização social. No início da década de 90 foram as chamadas "quebradeiras de coco babaçu" e os "quilombolas" que se colocaram na cena política constituída, consolidaram seus movimentos e articularam estratégias de defesa de seus territórios, juntamente com outros povos e comunidades tradicionais. Dentre os quais, estavam os "castanheiros" e os "ribeirinhos" [...]. Além destes, começaram a se consolidar no último lustro, as denominadas "comunidades de fundos de pasto" e dos "faxinais". Estes movimentos, tomados em seu conjunto, reivindicam o reconhecimento jurídico-formal de suas formas tradicionais de ocupação e uso dos recursos naturais ${ }^{8}$. Passam a se articular em torno de elementos que os unisse na busca de acessar seus direitos. Para isso acionam os mais variados elementos e entidades externas. Essa questão legal se consolidou quando o decreto $n^{\circ} 4.887$, de 20/11/2003, em conexão com a convenção 169 da Organização Internacional do Trabalho-OIT, regulamentou que a caracterização dos remanescentes das comunidades dos quilombos, atestada mediante auto identificação da própria comunidade. Tais comunidades, por sua vez, passaram a ser compreendidas também como grupos étnicos-raciais, segundo critérios de auto atribuição, com trajetória histórica própria, dotados de relações territoriais específicas, com presunção de ancestralidade negra relacionada com a resistência a opressão histórica sofrida ${ }^{9}$. As emergências quilombolas devem ser compreendido como sujeitos emergidos com os novos movimentos sociais no Brasil, dentre os quais, o movimento negro Unificado, com suas demandas contra o racismo e os preconceitos, dentre elas, as demandas das comunidades negras rurais por direitos ${ }^{10}$.

\footnotetext{
7 MONTEIRO, John Manuel. Apresentação. In: ARRUTI, José Maurício. Mocambo. Antropologia e História do processo de formação quilombola - Bauru, SP:EDUSC,2006.

${ }^{8}$ ALMEIDA, Alfredo Wagner Berno de. Prefácio da primeira edição. In: ACEVEDO, Rosa ; CASTRO, Edna. Negros do Trombetas: Guardiões das matas e rios. Ed. Cejup/UFPA-NAEA, Belém, 1998, 2ª edição, p.19.

${ }^{9}$ Idem.

${ }^{10}$ DOMINGUES, Petrônio. Movimento Negro Brasileiro: alguns apontamentos históricos. Movimento negro brasileiro: alguns apontamentos históricos. Tempo [on line]. 2007, vol.12, n.23, p.100-122.
} 


\section{EMERGÊNCIAS ÉTNICAS NO AMAZONAS: diálogos para uma história social} do movimento quilombola do Rio Andirá.

Na Amazônia, o exercício da produção do conhecimento sobre a temática quilombola se torna significativo e desafiador, especialmente no caso do estado do Amazonas, de onde emergem as Vozes quilombolas do Tambor (Novo Airão), do Barraco de São Benedito da praça 14 de Janeiro (Manaus), do Lago Serpa (Itacoatiara) e do Rio Andirá (Barreirinha, a partir de onde referenciamos nosso estudo).

José Maurício Arruti aponta três elementos para visualizar a questão "remanescente" de quilombo no Brasil. O primeiro seria "reconhecer a importância de percebê-los como emergentes"11; O segundo "reconhecer seu lugar, porque ainda mal definido tanto com relação às condições de acesso aos seus novos direitos, quanto às condições de exercício de sua nova identidade $[\ldots]^{\prime 12}$. O terceiro é estar atento para o fato de se lidar com um fenômeno não definido, mas em constituição constante, pois, "[...] a definição mais favorável daquilo que devem ser não depende apenas deles ou dos seus opositores, mas também do estado da correlação de forças em que aquelas comunidades e seus mediadores e concorrentes a mediadores estão inseridos [...]"13. Ganham relevos aí, profissionais das ciências humanas e sociais, com destaque para certas tarefas "na qual o papel interpretativo do antropólogo e do historiador parece ter destaque"14. (Re)articuladas com práticas passadas, ainda que não sejam estas as regras, ou modelos, "é preciso reconhecer a existência de intenções indenitárias nas lutas dessas comunidades"15. Afinal, "são a continuidade de um processo mais longo da história da escravidão e das primeiras décadas do pós-emancipação[...]. Não se trata de um passado móvel, como aquilo em que sobrou (posto nunca transformado) de um passado remoto" 16, portanto, “o desenvolvimento das comunidades negras contemporâneas é bastante complexo, com seus processos de identidade e luta por cidadania" ${ }^{17}$.

${ }^{11}$ ARRUTI, José Maurício Andion. A emergência dos "remanescentes": notas para o diálogo entre indígenas e quilombolas. MANA 3(2):7-38, 1997, p.29.

${ }^{12}$ Idem

${ }^{13} \mathrm{Idem}$

${ }^{14}$ Idem

${ }^{15} \mathrm{Idem}$

${ }^{16}$ GOMES, Flávio do Santos. Mocambos e quilombos: uma história do campesinato negro no Brasil. $1^{\mathrm{a}}$ ed. São Paulo: Claro Enigma, 2015, p.7

${ }^{17}$ Idem 
Compreender como os sujeitos sociais do início deste século constroem suas táticas para acessar "cenários de direitos" produzidos nos embates dos movimentos sociais desde as décadas finais do século XX, torna-se um grande desafio para a história regional e local. Dentre os impasses, está a produção de mecanismos que possibilitam identificar quem são essas tais comunidades? Como constroem seus processos presentes de luta por reconhecimentos, direitos, cidadania formal? Como (re)constroem as memórias sobre seus passados? Aliás, que passados são estes (re)construídos, a partir das demandas dos seus presentes? Como se conectam às demais experiências históricas dos mundos amazônicos, brasileiros e latino-americanos? Como produziram seus novos modos de ser e apresentar-se como quilombolas do Andirá?

Uma das possibilidades está no campo dos estudos da História Social, a partir da história social do negro no pós abolição ${ }^{18}$. Imbuídos com as preocupações em identificar, descrever e compreender os protagonismos visualizados nas e a partir das trajetórias e experiências de homens e mulheres que se articulam aos demais grupos sociais que se constituem como novos sujeitos políticos e de direitos. Promovem ações políticas de afastamento das concepções homogêneas de "caboclos" como eram tratados pelo Estado brasileiro ao longo do pós-abolição e constituindo-se étnica e politicamente como Quilombolas $^{19}$. Como produzem seus caminhos de acessos aos dispositivos constitucionais? Como construíram sua identificação étnica e territorialidades quilombolas? São questões que nos remetem para o fato de que "em vez de falar de identidade como uma coisa acabada, deveríamos falar de identificação, e vê-la como um processo em andamento"20. Haja vista que, "a identidade surge não tanto da plenitude da identidade que já está dentro de nós como indivíduos, mas de uma falta de inteireza que

\footnotetext{
${ }^{18}$ Para o campo dos estudos do pós-abolição ver RIOS, Ana Maria; MATTOS, Hebe Maria. O Pós-abolição como problema histórico: balanços e perspectivas. Topoi, V.5, 8, Jan. 2004, pp.170-198. Ver ainda as coletâneas ABREU, Marta; DANTAS, Carolina Vianna; MATTOS, Hebe (ORGs). Histórias do pósabolição no mundo atlântico: identidades e projetos políticos - volume 1/ organizado por Martha Abreu, Carolina Vianna Dantas e Hebe Mattos. - Niterói: Editora da UFF, 2014. - 13 MB; PDF; ABREU, Marta; DANTAS, Carolina Vianna; MATTOS, Hebe (ORGs). Histórias do pós-abolição no mundo atlântico: identidades e projetos políticos - volume 2 / organizado por Martha Abreu, Carolina Vianna Dantas e Hebe Mattos. - Niterói: Editora da UFF, 2014. - 3,8 MB; PDF; ABREU, Marta; DANTAS, Carolina Vianna; MATTOS, Hebe (ORGs). Histórias do pós-abolição no mundo atlântico: identidades e projetos políticos - volume 3 / organizado por - Niterói: Editora da UFF, 2014. - 7,2 MB; PDF.

${ }^{19}$ ROCHA, João Marinho da. Das Sementes aos Troncos: História e Memória do movimento quilombola do Rio Andirá. Tese de Doutorado em Sociedade e Cultura na Amazônia. Universidade Federal do AmazonasUFAM. Manaus 2019.

${ }^{20}$ HALL, Stuart. A Identidade cultural na pós-modernidade. Tradução Tomaz da Silva, Guaciara Lopes Louro - 11. Ed.- RJ:DP\&A, 2006, p.38-39
} 
é preenchida a partir de nosso exterior, pelas formas através das quais nós imaginamos ser vistos por outros" 21 .

Estamos atentos para o fato de que "falar dos quilombos e dos quilombolas no cenário político atual é, portanto, falar de uma luta política e, consequentemente, uma reflexão científica em processo de construção",22. Ensejamos diálogos com e, a partir da História Social e suas aberturas para a interdisciplinaridade, por considerá-la um campo que "[...] resulta num alargamento do interesse histórico[...]"23. Isto porque "em história, todos os níveis de abordagem estão inscritos no social e se interligam" 24 . A partir dos annalles, "a interdisciplinaridade serviria, [...] como base para a formulação de novos problemas, métodos e abordagens da pesquisa histórica"25. A temática dos "novos quilombos" é um desses temas que desafiam a historiografia Regional e Local. Isso ganha relevo quando tais comunidades estão referenciadas na Amazônia, historicamente esquadrinhada com irrelevância da presença africana escravizada e seus descendentes e, por isso, não mereceu estudos vultuosos ${ }^{26}$. Tomamos as abordagens interdisciplinares e dos processos socioculturais ${ }^{27}$ para visualizar as emergências quilombolas, "abrindo os muros da disciplina histórica para as demais ciências sociais, especialmente a sociologia e a antropologia social"28. Diálogos interdisciplinares que iluminam realidades, sujeitos e objetos com a presença negra no Amazonas no pós-abolição. "Esta aproximação com a antropologia levaria a história social, em sentido estrito, a privilegiar progressivamente abordagens socioculturais sobre os enfoques econômico-sociais até então predominantes" ${ }^{29}$. Olhares econômicos e políticos sobre as presenças negras no

\footnotetext{
${ }^{21}$ Idem.

${ }^{22}$ LEITE, Ilka Boventura. Os quilombos no Brasil: questões conceituais e normativas. Etnográfica, Vol. IV (2), 2000, pp. 333-354, p.333.

${ }^{23}$ CASTRO, Hebe. História Social. 1997. In: CARDOSO, Ciro Flamarion; VAINFAS, Ronaldo (orgs) Domínios da história: ensaios de teorias e metodologias. Rio de Janeiro: Campus, 1997. p.78.

${ }^{24}$ Idem

${ }^{25}$ CASTRO, Hebe. História Social. 1997. In: CARDOSO, Ciro Flamarion; VAINFAS, Ronaldo (orgs). Domínios da história: ensaios de teorias e metodologias. Rio de Janeiro: Campus, 1997. p.78.

${ }^{26}$ SILVA, Anaíza Vergolino e . Alguns elementos para o estudo do negro na Amazônia. Universidade Federal do Pará. Publicações avulsas no 8, Museu Paraense Emílio Goeldi, Belém-Pará- Brasil, 1968; VERGOLINO - HENRY, Anaíza ; FIGUEIREDO, Arthur Napoleão. A presença Africana na Amazônia Colonial: Uma notícia histórica. - Belém, Arquivo Público do Pará, 1990. 280p. (Documentos históricos, 1); BEZERRA NETO, José Maia Escravidão negra na Amazônia (sécs. XVII-XIX). - Belém: Paka-Tatu, 2001.

${ }^{27}$ SALLES, Vicente. $O$ negro no Pará. sob o regime de Escravidão. Ed.Ufpa,1971; SALLES, Vicente. O negro na sociedade Paraense. Textos reunidos. Belém: Paka-Tatu, 2004; SALLES, Vicente. Os mocambeiros e outros ensaios. - Belém: IAP, 2013.

${ }^{28}$ CASTRO, Hebe. História Social. 1997. In: CARDOSO, Ciro Flamarion; VAINFAS, Ronaldo (orgs). Domínios da história: ensaios de teorias e metodologias. Rio de Janeiro: Campus, 1997, p.80-81

${ }^{29}$ Idem, p.84
} 
Amazonas. Essa pareceu ser a tônica das explicações que produziram uma "historiografia do silêncio"30 sobre tal temática. No entanto, quando se decide "privilegiar progressivamente abordagens socioculturais sobre os enfoques econômico-sociais", as significâncias das presenças negras aparecem e são amplificadas nos planos da cultura. "Foi a partir de suas concepções e perspectivas (as da História Social) que os chamados 'temas malditos', [...] encontraram guarida nessa historiografia[... $]^{31}$.

Diante das questões levantadas acima abriram-se novas perspectivas metodológicas na visualização das realidades sociais diversas, como estas "Vozes" que emergem dos silêncios do rio Andirá, e que, amplificamos neste estudo, por meio da metodologia da História Oral. "O trabalho de produção de fontes orais pode ser dividido em três momentos: a preparação das entrevistas, sua realização e seu tratamento" ${ }^{32}$. A metodologia possibilitou explicitar e compreender como os tais sujeitos sociais do Rio Andirá produziram seus discursos, pois, "história oral permite o registro de testemunhos e o acesso a 'histórias dentro da história' e, dessa forma, amplia as possibilidades de interpretação do passado"33. Sobre as fontes, vale lembrar que "a história oral é uma metodologia de pesquisa e de constituição de fontes para o estudo da história contemporânea surgida em meados do século XX, após a invenção do gravador a fita"34. Ainda segundo Albert, "ela consiste na realização de entrevistas gravadas com indivíduos que participaram de, ou testemunharam, acontecimentos e conjunturas do passado e do presente" ${ }^{\text {35 }}$, como é o caso da personagem Maria Amélia dos Santos Castro.

\section{Da Construção de Memórias do Cativeiro}

[...] Papai contava que meu avô, veio de Angola, da África, como escravo dos portugueses. Então, esse meu avô, por parte de pai, era Benedito Rodrigues da Costa que veio nos navios africanos pra servir os portugueses. Ele tinha três irmãos, uma irmã, que era a tia Maria e mais dois irmãos: o tio Francisco e tio João. Tendo estes três partidos para lugares ignorados, ninguém sabe pra onde. Nessa época iam pro Pará e outros lugares; não sabemos pra onde eles foram $[\ldots]^{36}$

\footnotetext{
${ }^{30}$ SAMPAIO, Patrícia M.(Org.). O fim do silêncio - presença negra na Amazônia. Belém: Açaí/CNPq, 2011.298p.

${ }^{31}$ FENELON, Déa Ribeiro. Cultura e História Social: Historiografia e pesquisa. Proj. História, São Paulo, (10), dez. 1993.p.p.73-90, p.76.

32 ALBERT, Verena. Histórias dentro da História. In: PINSK, Carla Bassanezi. Fontes Históricas. 3 ed. São Paulo: Contexto, 2011, p.171

${ }^{33}$ Idem, p. 155

${ }^{34}$ Idem

${ }^{35}$ Idem

${ }^{36}$ Maria Amélia dos Santos Castos. Entrevista. Agosto de 2016. Parintins/AM.
} 
Não tratamos aqui da escravidão negra na Amazônia em si, mas acerca dos processos contemporâneos de construção de "identidade étnica"37 e "territorialidades específicas" ${ }^{38}$. De onde os sujeitos sociais auto identificados como quilombolas, vêm (re)construindo uma memória do cativeiro, segundo a qual, ligam suas trajetórias socio históricas aos mundos da escravidão e pós-abolição no Amazonas. Decidimos metodologicamente seguir os fios das memórias para compreender a reconstrução da história sobre si. (Re)constituídas no Âmbito do Movimento Social Quilombola do Andirá - MSQA pelas vozes etnicizadas, politizadas. Questão que precisa ser compreendida à luz de vozes como as que contemporaneamente emergem do rio Andirá, apesar e além das reduzidas estatísticas para aquelas áreas fronteiriças Amazonas/Pará. Isto também implica (re)pensar concepções sobre fontes e métodos, pois, "quando os historiadores começam a fazer novos tipos de perguntas sobre o passado, para escolher novos objetos de pesquisa, tiveram de buscar novos tipos de fonte para suplementar os documentos oficiais" ${ }^{39}$. Nisso, "alguns se voltaram para a história oral; outros, à evidência das imagens; outros, à estatística. Também se provou possível reler alguns tipos de registros oficiais de novas maneira ${ }^{40}$.

No Andirá existe memórias vivas acerca das origens, muitas das quais pautadas na tradição oral ${ }^{41}$, "vividas por tabela" e que são remetidas à uma certa ancestralidade angolana com passagens pelo Pará. Os agentes do movimento de luta produziram mecanismos para (re)constituir politicamente, como faz a presidente da Federação das Organizações Quilombolas do município de Barreirinha - FOQMB quando justifica de onde saem as forças de seus discursos. "Eu tive oportunidade de conversar um pouco com as pessoas antigas. Pessoas que me passou a memória, de uns cento e oito anos, que faleceu, dia 19 de maio de 2010"42. Tal assertiva "além do valor moral [...] e de sua adesão

\footnotetext{
${ }^{37}$ BARTH, Friedrik. Os Grupos Étnicos e Suas Fronteiras. In: O Guru, O Iniciador e Outras variações Antropológicas. Rio de Janeiro: Contra Capa, 2000. p. 25-68.

38 . ALMEIDA, Alfredo Wagner Berno de. Terra de quilombo, terras indígenas, "babaçuais livre", "castanhais do povo", faixinais e fundos de pasto: terras tradicionalmente ocupadas. - 2. ${ }^{a}$ ed, Manaus: PGSCA - Ufam, 2008; ALMEIDA, Alfredo Wagner Berno de. Territórios e territorialidades específicas na Amazônia: entre a "proteção" e o "protecionismo". Caderno CRH, Salvador, v. 25, n. 64, Jan/Abr. 2012. p. 63-71.

${ }^{39}$ BURKE, Peter. A história dos acontecimentos e o renascimento da narrativa. In: BURKE, Peter (Org.). A escrita da História. Novas perspectivas. Tradução de Magda Lopes. São Paulo: Editora Unesp, 2011, p. 25.

${ }^{40}$ Idem

${ }^{41}$ HAMPANTÊ BÂ, Amadou. Tradição Viva. In: ZERBO, Joseph Ki (org.). História geral da África, I: Metodologia e pré-história da África. 2.ed. rev. Brasília: UNESCO, 2010.

${ }^{42}$ Maria Amélia dos Santos Castos. Entrevista. Agosto de 2016. Parintins/AM.
} 
a uma "cadeia de transmissão"43, atesta e serve também como "uma garantia suplementar de autenticidade é fornecida pelo controle permanente de seus pares ou dos anciãos que os rodeiam, que velam zelosamente pela autenticidade daquilo que transmitem e que os corrigem no menor erro"44. Dentre os "antigos" referidas que passou a "memória por tabela", estão "Ferro Birro" de 90 anos, Manuel Eugenio, 104 anos e, no caso citado "tia Ludia", como era conhecida no Andirá a centenária Maria Ludia Rodrigues ${ }^{45}$, fruto de casamentos interétnicos entre quilombolas, indígenas e comerciantes judeus adentrados no Andirá.

Meu bisavô, veio da África. O nome dele era, Benedito Rodrigues da Costa. Girônima da Costa Rodrigues, mãe da vó [...], casou com um [...] o homem que veio da África". Me contaram né! [...] agora ele eu não vi nada por aí. Benedito Rodrigues eu não vi não. [...] só vi minha vó. Ele (papai) contava que a mãe dele [...], a finada da minha avó já ia embora andando, encontrou com esse homem, com o Benedito Rodrigues, o preto, da África, e, casou com ele, e aí vieram para Baixo Amazonas. [...]. Quando era criança ouvia muita história dessa escravidão, essas coisas dos escravos! Apanhavam muito, tudo se ouvia ainda. Meu bisavô já era liberto [...], era, paresqui era. Depois a Izabel que libertou, a princesa Izabel, ela foi quem libertou os pretos [...]. Se não fosse abaixo de Deus ela, sei lá como não era! Ela libertou tudo! [...]. Esta história [libertação], eu soube aqui [Manaus] e lá em Parintins, tudo por aí sabiam a história deles [...]. ${ }^{46}$.

[...] Eu não cheguei a conhecer o velho Benedito Rodrigues, o preto carimbado que foi pai de todos eles e o primeiro que veio pra cá. Quando me entendi ele já tinha morrido. Não conheci [...] Por que digo carimbado? Ah, isso era meu padrasto que contava. Ele sim conheceu o velho. Ele dizia que o velho tinha um carimbo no rosto, acho que uma marca que devia ser igual carimbo. Então ele contava que ele era um preto carimbado ${ }^{47}$.

Devidamente registradas e (re)organizadas no contexto do MSQA, tais memórias, acrescidas a outras com igual teor, garantiram reconhecimento "dos pretos do Matupiri" como grupo étnico. Realizar esforços interpretativos das Sociedades e das Culturas na Amazônia, por meio das ações políticas de sujeitos, coletividades e dos seus muitos processos, práticas socioculturais e espaços simbólicos de pertencimentos, pode indicar

\footnotetext{
${ }^{43}$ HAMPANTÊ BÂ, Amadou. Tradição Viva. In: ZERBO, Joseph Ki (org.). História geral da África, I: Metodologia e pré-história da África. 2.ed. rev. Brasília: UNESCO, 2010, p. 181.

${ }^{44} \mathrm{Idem}$

${ }^{45}$ As memórias de Ludia - filha de Manoel Rodrigues da Costa com Esmeraldina-foram um dos principais indícios sob o qual pautou-se a FOQMB para produzir suas "viagens da memória". A ela juntam-se outros centenários, a exemplo de Manuel Eugênio. Nenhum dos dois conheceram os "puracas", apenas escutaram seus pais falarem do "preto marcado". Este fato, a nosso ver, confere mais anterioridade à ocupação afro no Andirá. O que deixa em aberto para novas investidas de pesquisa que intentem rumar pelos arquivos paroquias e cartoriais. Ambos centenários falecidos ao longo do processo de luta por reconhecimentos, mas que ajudaram a balizar os contornos da memória do cativeiro que se produziu no MSQA.

${ }^{46}$ Maria Ludia Rodrigues, 108 anos. Entrevista. Maio de 2010. Manaus Amazonas. Realizada por Emanuel Farias Jr. Arquivos da FOQMB.

${ }^{47}$ Manoel Eugênio, 104 anos, Pagoa, em 15/06/2015. Entrevista In: Siqueira (2016, p.37). RTID.
} 
"outras histórias" sobre o pós-abolição no leste amazonense. Práticas socioculturais como a marujada em homenagem a São Benedito evidenciam-se também nos “corpos negros"48, que se movem, a partir de batuques e ritmos emanados do gambáa ${ }^{49}$. Não se trata aqui de afirmar pertenças exclusivas de certas manifestações a determinados grupos étnicos, mas de compreender tais práticas são efetivadas e que sentidos isso tem para os sujeitos sociais no âmbito de suas lutas por direitos. "Temos que ter foco - não para afirmar que a cultura é localizada em algum lugar, mas como uma forma de identificar onde ela está sendo produzida e reproduzida"50.

Além daqueles batuques do gambá, acrescentamos ainda as "proezas dos $\operatorname{antigos}^{51}$ " que aprenderam a entrecruzar práticas religiosas diversas nos terreiros da "antiga ponta ${ }^{52}$ " onde se formou o quilombo "Santa Tereza do Matupiri”. Presentes também nos arredores lago Jauari sob efeitos das inalações do cigarro de "tauari" que "é tirado para o "trabalho", para fazer o cigarro do curador[...]. Usam pra fazer as benzição ${ }^{53}$. Lembrar e reconstituir práticas e ensinamentos "dos grandes mestres das proezas" significa também credenciar-se àqueles antigos tempos e espaços . Rememorálos nos contextos das lutas sociais contemporaneous é valorizar suas identidades e patrimônio, tendo em vista que, "o apego religioso ao patrimônio transmitido exprime se em frases como: ‘Aprendi com meu Mestre', 'Aprendi com meu pai', 'Foi o que suguei no seio de minha mãe" "54. Nesse sentido, "Deolindo, Salatiel, Manoel Rodrigues, Nercia, Terezita e outros mais" "55, são mestres que ensinavam aos seus, que "a gente tem que ter alguém, a gente tem que ter defesa no corpo e defesa na alma" ${ }^{56}$. Gentes que recebiam ancestralidades africanas e ameríndias, por vezes hibridadas com as práticas do catolicismo popular, traziam saúde e afastavam as doenças. "Andavam sobre brasas"57, e ou também, "faziam canoas roubadas voltarem" 58 , dentre outras coisas do gênero. "Eles

\footnotetext{
48 ANTONACCI, Maria Antonieta. Memórias ancoradas em corpos negros. São Paulo: Edusc, 2013.

49 AVILA, Cristian Pio. Os Argonautas do Baixo Amazonas. Tese. Antropologia Social. Ufam, ManausAM, 2016.

${ }^{50}$ BARTH, Friedrik. Etnicidade e o conceito de cultura. Antropolítica, n. 19. Niterói: UFF, 2005. p.p1530, p.16.

${ }^{51}$ Maria Amélia dos Santos Castro. 57 anos. Entrevista. Setembro de 2017. Quilombo Santa Tereza do Matupiri.

${ }^{52}$ Idem.

${ }^{53}$.Idem.

${ }^{54}$ HAMPANTÊ BÂ, Amadou. Tradição Viva. In: ZERBO, Joseph Ki (org.). História geral da África, I: Metodologia e pré-história da África. 2.ed. rev. Brasília: UNESCO, 2010, p.174.

${ }^{55}$ Idem.

${ }^{56}$ Idem.

${ }^{57}$ João de Paula. Entrevista. Julho de 2016. Quilombo de Ituquara.

${ }^{58}$ Adelso Freitas de Castro. Entrevista. Julho de 2016.Quilombo Trindade.
} 
mostravam as proezas mesmo!, faziam com que as coisas acontecessem" ${ }^{\text {"59 }}$. Práticas comuns antes da romanização das comunidades do rio Andirá e Baixo Amazonas ${ }^{60}$. Fenômeno que, dentre outras coisas "isolou esse lado ${ }^{61 "}$ e ousou adotar a monocultura religiosa e étnica no Andirá. Isto transformou mestres de curas e proezas em puxadores de ossos, e de barrigas/parteiras, apenas.

"A cultura está sempre em fluxo e em mudanças, mas também sempre sujeita a formas de controle. [...]Vejo três processos contrários à variação [...]: os processos de controle, silenciamento e apagamento das experiências" ${ }^{62}$. É o que parece ter ocorrido com as irmãs Nércia e Terezita. Esta última, por exemplo: "tinha quatro cores na roupa dela: vermelho, preto, branco e amarelo. Usava uma fita vermelha atravessada no peito ou fita preta amarrada no cós da saia. Isso apresentava imagem do que ela era. Até em 1980 elas ainda faziam suas proezas aí na "Antiga ponta" e aqui nas casas deles" ${ }^{63}$. No entanto, lamenta a liderança, "[...] os padres vinham aqui. Acho até que foi isso que afugentou um pouco, por que elas frequentavam muito, aí foram esquecendo. [...] A Tia Nércia adoeceu por que estava querendo deixar os mestres[...]. Ela 'tornou' voltar'.

Saberes e práticas híbridas sócio culturalmente, invisibilizadas continuamente no pós abolição no Amazonas. No entanto, politicamente tais memórias silenciadas são (re)constituídas no contexto do MSQA pelos descendentes daqueles antigos mestres das proezas, que aprendendo sobre si, compreendem suas ancestralidades. Sujeitos que distribuíram cultura como resultados de suas experiências socio religiosas. Esforços e ações políticas relevantes, na medida em que "devemos pensar a cultura como algo distribuído por intermédio das pessoas, entre as pessoas, como resultado das suas experiências"64. Essas práticas ressurgem com mais firmeza, haja vista que, "a cultura está em um estado de fluxo constante"65 e portanto, "não há possibilidade de estagnação

\footnotetext{
${ }^{59}$ Maria Amélia dos Santos Castro. 57 anos. Entrevista. Setembro de 2017. Quilombo Santa Tereza do Matupiri

${ }^{60}$ Institucionalização de práticas religiosas segundo a teologia romana. Muita após a presença dos padres do Instituto da Missões Externas - PIME. Inúmeras práticas do catolicismo popular e de curas passaram ao plano das invisibilidades, não extintas, mas reduzidas a ambientes domésticos e estigmatização de seus praticantes. Ver CAMPOS, Pe. Manuel do Carmo. A decadência do catolicismo popular na região parintinense (1955-1975). Revista de Cultura Teológica. 1995, p. 109-117.

${ }^{61}$ Maria Amélia dos Santos Castro.57 anos. Entrevista. Setembro de 2017. Quilombo Santa Tereza do Matupiri.

${ }^{62}$ BARTH, Friedrik. Etnicidade e o conceito de cultura. Antropolítica, n. 19. Niterói: UFF, 2005. p.p15$30, \mathbf{p . 2 2}$.

${ }^{63}$ Idem.

${ }^{64}$ BARTH, Friedrik. Etnicidade e o conceito de cultura. Antropolítica, n. 19. Niterói: UFF, 2005. p.p1530 p.17.

${ }^{65}$ Idem
} 
nos materiais culturais, porque eles estão sendo constantemente gerados, à medida que são induzidos a partir das experiências das pessoas. [...] algo que está basicamente em um estado de fluxo"66.

Dadas as limitações de nossas fontes e os objetivos desta discussão inicial, não sabemos se os tais angolanos, reivindicados socialmente pelas memórias do Andirá vieram direto para os portos do Pará e ou Maranhão, ou ainda pelo tráfico interprovincial. Mais ainda, não podemos afirmar se são descendentes de africanos trazidos para as fazendas de gado e agricultura do Baixo Rio Amazonas, amocambados nos rios Tapajós, Trombetas, Erepecuru, Curuá para onde registram-se quilombos históricos ${ }^{67}$, ou, se estão ligadas às experiências como as registradas no Rio Mamuru, no e para além contexto da Cabanagem $^{68}$. E, ou também, nos fins do século XIX nos momentos de trânsitos abertos entre as províncias do Pará e Amazonas ${ }^{69}$, versão oficializada pela federação quilombola e sobre a qual produzimos nossas análises, por ser nosso objeto a memória e a história do movimento quilombola do Andirá, que neste recorte se ocupa das ações da liderança Maria Amélia.

\section{Vozes da Mata}

Os protagonismos quilombolas são visualizados naquilo que denominados de "Vozes da Mata", atos protagonizados principalmente por mulheres que marcam o movimento quilombola do Andirá. A Mata é visualizada como entidade que gera, guarda e que autoriza as falas dos sujeitos por ela enviados. Sujeitos e falas visibilizadas nas histórias de mulheres, que aqui são pluralizadas em "Geronimas, Terezas, Cristinas, Terezitas, Nércias, Ambrózias, Inêses, Esmeraldinas, Cremildas e Amélias”, para citar

\footnotetext{
${ }^{66}$ Idem

${ }^{67}$ SILVA, Anaíza Vergolino e . Alguns elementos para o estudo do negro na Amazônia. Universidade Federal do Pará. Publicações avulsas $n^{\circ}$ 8, Museu Paraense Emílio Goeldi, Belém-Pará- Brasil, 1968; VERGOLINO - HENRY, Anaíza ; FIGUEIREDO, Arthur Napoleão. A presença Africana na Amazônia Colonial: Uma notícia histórica. - Belém, Arquivo Público do Pará, 1990. 280p. (Documentos históricos, 1); GOMES, Flávio do Santos . A Hidra e os Pântanos: quilombos e mocambos no Brasil (sécs. XIII e XIX). Tese (Doutorado em História) - UNICAMP/SP, 1997; SAMPAIO, Patrícia M. Espelhos partidos: etnia, legislação e desigualdade na Colônia. - Manaus: EDUA, 2012.

${ }^{68}$ SOUZA, Cónego Francisco Bernardino de. Lembranças e curiosidades do Valle do Amazonas. Pará: Tvp do futuro, 1878; REIS, Arthur César Ferreira. As Origens de Parintins. Editado pelo governo do Estado do Amazonas. Secretaria de imprensa e divulgação. Palácio Rio Negro, Manaus-Amazonas, 1967; REIS, Arthur César Ferreira. História do Amazonas. Belo Horizonte, Manaus: Superintendência cultural do Amazonas, 1989.

${ }^{69}$ SIQUEIRA, João. Relatório Técnico de Identificação e Delimitação- RTID do território quilombola do rio Andirá, Manaus-Am, 2016; RANCIARO, Maria Magela de Andrade. "Os cadeados não se abriram de primeira": processos de construção identitária e a configuração do território de comunidades quilombolas do Andirá. Tese em Antropologia Social. Universidade Federal do Amazonas- UFAM. Manaus. 2016.
} 
algumas delas. Maria Amélia traduziu as esperanças sobre a "certidão da Palmares" e futura demarcação do território. "eu acredito que tudo que vai ser feito está aí nesses mapas que fizemos. É agora que nós vamos ser reconhecidos! E a gente mostrou tudo; as áreas devastadas. Aí, as pessoas vão saber aonde é que a gente mora; o que fazemos. Tudo vai ser bem encaminhado" 70 . Finaliza refletindo que, "estávamos esquecidos; agora, não! Todos vão saber como vivemos, qual é a cabeceira que a gente tira o nosso sustento. Daqui pra frente, a gente vai sim, conseguir: vai ser feito aquilo que queremos; aquilo que nós esperamos" $"$.

A certificação "da Palmares", aparece nas narrativas quilombolas como garantidora/indicadora de possibilidades de mudanças para aquelas comunidades que mobilizaram suas memórias para os mais variados conhecimentos sobre si. As vozes quilombolas indicam reações e lutas contra as materializações de discursos hegemônicos acostumados a "amedrontar" aquelas comunidades. Dúvidas que dividiam os moradores e produziam conflitos frontais entre integrantes do MSQA, ao ponto de paralisar os processos de lutas por diferenciação étnica iniciados em certas comunidades ${ }^{72}$. A) a quem compete emitir os certificados de auto identificação? B) De como proceder para acessar direitos previstos nos dispositivos constitucionais? $C$ )Seu reconhecimento como quilombolas seria mesmo fruto das vontades do prefeito e do pessoal do meio ambiente?. Processo marcadas inicialmente pelos mapeamentos das memórias e tradições espalhadas pelas cinco comunidades, e posteriormente pelas materializações de tais memórias nos processos socio culturais organizados (festas, danças, festivais e feiras culturas, etc), já em parceria com as escolas locais. Os povos e comunidades tradicionais “ [...] apresentam uma consciência de si mesmo enquanto grupo distinto com identidade coletiva própria e formas de organizações intrínsecas que não se reduzem à ocupação econômica ou à relação com os meios de produção" 73 . Para compreender suas mobilizações "[...] devem ser considerados os elementos de auto identificação e de consciência das suas próprias

\footnotetext{
70 AMÉLIA, Maria. Trilhas percorridas por uma militante quilombola: vida, luta e resistência. Maria Magela Mafra de Andrade Ranciaro, org.; Alfredo Wagner Berno de Almeida, ed.; Rio de Janeiro: Casa 8, 2016, p.60.

${ }^{71}$ Idem.

${ }^{72}$ O relatório de Siqueira(2016) denuncia que as primeiras ações das comunidades para a certificação junto à FCP foram apaziguadas e paralisadas, muito por causa de tais impasses e querelas internas. Essa questão também é amplamente demonstrada por Ranciaro(2016); Amélia(2016).

${ }^{73}$ ALMEIDA, Alfredo Wagner Berno de. Agroestratégias de desterritorialização: os direitos territoriais e étnicos na mira dos estrategistas dos agronegócios. In. RODRIGUEZ, José Ezequiel Basani Et Ali (Orgs). Povos tradicionais, fronteiras e geopolítica na América Latina: uma proposta para a Amazônia - Manaus: Edua, 2014. 266 p., p.118.
} 
necessidades. A partir deles pode-se afirmar que fatores étnicos e identitários mostramse capazes de delinear suas diferenças face a outros grupos"74.

Num movimento de produção, politização e institucionalização da memória ancestral para (re)querer acesso a direitos o manuseio e trato com as questões formais e administrativas, os diálogos com agentes externos, passaram a disputar não só as memórias dos antigos, mas o poder de comunicá-las, de dizê-las, de traduzi-las politicamente e nisso lograr êxito e reconhecimentos para a suas coletividades. Estamos nos referindo a: 1. Episódio da busca por alguém com letras na cidade para gerir inicialmente a federação quilombola do Andirá, no caso a Técnica de enfermagem Maria Cremilda, saída das cabeceiras grande(Matupiri) ainda adolescente para buscar as letras; 2. A eleição e posterior questionamento das capacidades intelectuais de Maria Amélia. Os impasse em torno de quem pode representar o grupo parece valer principalmente para o processo de marcação de posições nos contextos dos conflitos produzidos e administrados no âmbito da Federação. Algumas dessas lideranças, constituídas como "guardiões da memória"75 aprenderam a conectar tradição e inovação, o fazem num trabalho de produção de identidades coletivas e lutas pelos reconhecimentos. Em seus contextos contemporâneos como sujeitos políticos e de direitos, ressignificam elementos como as "memórias territoriais", ajudam a fomentar e dar sentidos étnicos aos espaços simbólicos de pertencimentos. Elementos que foram, por decisões e ações políticas no curso das lutas por diferenciação, sendo (re)constituídos, institucionalizados, materializados, em alguns casos, ensinados em espaços formais (escolas) e também em espaços não formais e socioculturais de educação histórica sobre si (festas, festivais, feiras culturais, danças, práticas sociais, de trabalho e lazer, dentre outras).

As lideranças buscaram parcerias e incorporaram o discurso de busca de ajuda fora. "Olha, quando eu não sabia eu procuro saber!"76. Este relato reflete sobre as ações políticas de protagonismos nos percursos de lutas que foram e objetivaram-se em movimentos políticos, por meio dos entrelaçamentos de elementos internos (como da memória e da tradição), com elementos externos (como de mediadores para os acessos aos dispositivos constitucionais). Tais ações políticas objetivaram tecer possibilidades para acessar direitos constitucionalmente postos desde 1988, tanto que foram se auto

\footnotetext{
${ }^{74}$ Idem

75 GOMES, Ângela de Castro. A guardiã da memória. Acervo - Revista do Arquivo Nacional, Rio de Janeiro, v.9, nº 1/2, jan./dez. 1996, p.p.17-30.

${ }^{76}$ Maria Amélia dos Santos Castro, 56 anos. Entrevista. Agosto de 2016. Parintins-AM.
} 
conhecendo no sentido em que mapearam as memórias dos mais velhos ainda vivos e parte de uma memória oral "vivida por tabelas", nas comunidades próximas onde sabiam existir parentes antigos, principalmente os descendentes diretos de Benedito Rodrigues da Costa e de Geronima Sateré, depois alargados para os descendentes de Benedito Rodrigues da Costa com Maria Tereza Albina de Castro. Trajetórias, que não apenas cruzam os destinos de Benedito Rodrigues da Costa, como também constam nas referências da Federação quilombola do Andirá, narrativas oficiais onde o negro Benedito tem lugar e prestígio garantidos, em detrimento de suas companheiras e dos muitos filhos nascidos a partir de tais relações. Pontuamos tais questões, porque também existe narrativas que objetivam inserir tais mulheres como protagonistas, como aliás o foram. Ao contrário de Gerônima, esquecida no curso do movimento, a "velha Tereza", por exemplo, aos poucos vem ganhado espaço nas narrativas mais recentes após a “certificação da Palmares”, que a coloca como Matriarca de comunidade Santa Tereza, já que seu núcleo familiar esteve ocupando a "antiga ponta e de lá espalharam-se"77.

Nos contextos iniciais para a auto identificação quando ocorreu os processos de "procuração de negros", o MSQA foi acionado e assim precisava agir para garantir narrativas mais diretas e indicadoras das pretensas origens, e isso foi muito bem realizado em torno da figura de Benedito Rodrigues da Costa. Ainda que das duas grandes versões haja divergências sobre as maneiras de suas chegadas, nenhuma delas desfoca suas atenções da centralidade dessa figura no grupo de negros ali chegados, daí por que os demais sujeitos, "tomaram rumos ignorados"; diríamos, espalharam-se na região, na história e por isso, fugiram aos primeiros mapeamentos de memórias, porque talvez, não dava, naquele momento para "encaixar" nos projetos de memória, que se etnicizava e politizava-se para demandar direitos face ao Estado. Mas isso são as marcas dos processos constituintes da memória e da identidade, como nos alerta Pollack(1989, 1992), ao referirse ao silêncio e ao esquecimento, elementos inerentes à tais construções(da memória e da identitárias).

Além de um projeto de memória, onde a "memória territorial" teve sua vez e valor, o MSQA agregou-se às redes e instituições que amplificaram suas vozes. Se seu maior agente externo, Projeto Nova Cartografia Social da Amazônia - PNCSA tratava naquele momento acerca do território, por aí também cuidou de enveredar a memória em seus ordenamentos iniciais, materializando suas memórias em produtos escritos, agregados da

\footnotetext{
${ }^{77}$ Maria Amélia dos Santos Castro, 56 anos. Entrevista. Agosto de 2016, Parintins, AM
} 
linguagem privilegiada para os embates em busca de direitos. Foi o caso do fascículo "Quilombolas do Andirá"78 e o "livro de memórias da liderança Maria Amélia"79, dois instrumentos amplamente utilizados como recursos nas lutas do MSQA. Em tal fascículo foram representados, a partir das memórias locais, mapas sociais do pretenso território quilombola tradicionalmente utilizado pelos antepassados. "Os galhos” (Boa Fé, Ituquara, São Pedro, Trindade e núcleos quilombolas de São Paulo, Pagoa, Lírio e São Marcos) desceram ao Matupiri, onde puderam "passar cinco dias como foi feito de acordo com o povo. Hoje, vocês tão fazendo aqui os mapeamentos, vocês tão fazendo os GPS" ${ }^{80}$. Dessa forma, serviu, como instrumento político para solidificar os caminhos da certidão "da palmares" e em seguida na reivindicação pela demarcação do território, processo tenso e ainda em andamento, haja vista que, "Os obstáculos e entraves à titulação das terras das comunidades remanescentes de quilombos não podem ser reduzidos tão somente a ‘defeitos' na engrenagem da máquina administrativa estatal" ${ }^{\text {. P1 }}$ Para este autor, "há várias configurações neste jogo de poder que transcendem as questões de operacionalidade e as rubricas orçamentárias. Há tipos de entraves [...]que efetiva e implicitamente inibem as instâncias de poder competente" ${ }^{\nexists 2}$. O tal fascículo foi transformado em uma ferramenta política, especialmente contra os vizinhos "intrusos".

Nas muitas incursões em busca de agregar valores às memórias e à tradição oral, qualificando-as no jogo político e étnico do MSQA, as lideranças perceberam que não podem mais confiar apenas em sujeitos locais para sanar suas dúvidas. Agiram procurando sair das cordas dos discursos locais, nos quais já se encontravam presas muitos das comunidades que demovaram em se auto identificar. Diziam que não ia dar em nada o movimento por diferenciação étnica, por já saberem que "o prefeito e pessoal do meio ambiente" não queriam assinar, demonstrando desconhecimentos sobre os processos técnicos referentes a auto identificação. As lideranças saem das águas do

\footnotetext{
${ }^{78}$ Mapeamento Social como instrumento de gestão territorial contra o desmatamento e a devastação: processos de capacitação de povos e comunidades tradicionais: Quilombolas do rio Andirá: Santa Tereza do Matupiri, São Pedro, Trindade, Boa Fé e Ituquara/Barreirinha-Amazonas, 4/coordenação do projeto, Alfredo Wagner Berno de Almeida; equipe de pesquisa, Maria Magela Mafra de Andrade Ranciaro...[et al]. - Manaus:UEA, 2014.

${ }^{79}$ AMÉLIA, Maria. Trilhas percorridas por uma militante quilombola: vida, luta e resistência. Maria Magela Mafra de Andrade Ranciaro, org.; Alfredo Wagner Berno de Almeida, ed.; Rio de Janeiro: Casa 8, 2016.

80 AMÉLIA, Maria. Trilhas percorridas por uma militante quilombola: vida, luta e resistência. Maria Magela Mafra de Andrade Ranciaro, org.; Alfredo Wagner Berno de Almeida, ed.; Rio de Janeiro: Casa 8, 2016, p.p.67-68

${ }^{81}$ Idem, p. 118 .

${ }^{82}$ Idem
} 
Andirá e começam a indagar nos espaços de fora, para onde apontam as redes e conexões construídas com os agentes externos. É o que fez Maria Amélia, a essa altura um tanto desconfiada e alertada pela história, resolveu fazer as provocações que levaram o Ministério Público Federal - MPF ao município de Barreirinha e às águas do Andirá. “Quando o Dr. Júlio Junior veio aqui - do Ministério Público Federal - eu perguntei pra ele qual era o nosso direito dentro do nosso território remanescente de quilombo?" ${ }^{83} \mathrm{~A}$ liderança indagou "se realmente era certo a presença pelo município, ou se tinha outro órgão diferente?" 84 , teve como resposta que “- Não, o município não resolve nada do problema de vocês. O que vem resolver o problema[...] é a Fundação Palmares, ele como trabalhava no Ministério Público Federal que é outra voz e o INCRA" ${ }^{\text {"85 }}$

Naquele momento as lideranças procuravam agir dentro das "normas" das legislações vigentes seus processos de auto identificação ${ }^{86}$. Fato já tentado por lideranças anteriores como Maria Cremilda Rodrigues dos Santos, mas que, estiveram muito presas e comprometidas aos afagos daquelas vozes municipais. Além das suas poucas conexões e parcerias reais com os cenários e órgãos extra locais, que pudessem assessorá-la, de fato, e cuidar da implementação do dispositivo constitucional. O contrário parece ter ocorrido com a gestão de Maria Amélia e seus agentes externos, a exemplo do PNCSA, com seus projetos e interesses definidos sobre as questões das identidades coletivas e territorialidades de povos e comunidades tradicionais.

Após sua ousada questão para o agente do MPF Maria Amélia passa a ter certeza de que deveriam continuar para além daquele rio Andirá, se quisessem ter de fato e de direito, reconhecimentos da Fundação Cultural Palmares- FCP (certificação como remanescentes) e do Instituto Nacional de Colonização e Reforma Agrária INCRA(titulação das terras). As análises dos "arquivos de memória" e das “documentações oficiais da Federação", dão conta que essa liderança não construiu, por isso mesmo, as tais "boas relações" 87 com os agentes públicos do município de Barreirinha. Esclarecidas as dúvidas a partir "das pessoas certas e amigas" ${ }^{88}$. Maria Amélia lembra que a partir de então "foi que o pessoal entenderam que nós não podia

\footnotetext{
${ }^{83}$ Maria Amélia dos Santos Castro. 56 anos. Entrevista. Julho de 2016. Santa Tereza do Matupiri.

${ }^{84}$ Idem.

${ }^{85}$ Idem

${ }^{86}$ Sobre os registros e atos formais emitidos pela FOQMB no sentido de dar continuidade aos seus processos de luta por diferenciação étnico, ver Ranciaro(2016), também o RTID Siqueira(2016).

${ }^{87}$ No sentido atribuído pelos órgãos municipais. Haja vista que, tal liderança bateu de frente com certas atitudes e práticas costumeiras que desautorizavam as lutas quilombolas em favor de outros segmentos ali presentes, como madeireiras e pecuaristas.

${ }^{88}$ Maria Amélia dos Santos Castro, 56 anos. Entrevista. Agosto de 2016. Parintins-AM.
} 
esperar do município[...]. Por isso que vem de Manaus, de Brasília, de Parintins. [...] não passa por Barreirinha, porque remanescente somo nós não eles!. É por isso que venham procurá nós" $" 89$.

Influenciadas por cenários externos, nesse ambiente de diálogo intenso com as experiências das outras partes do país, especialmente do oeste paraense, as comunidades quilombolas do Andirá, também iniciaram seus processos de luta:

\begin{abstract}
A Luta por reconhecimento começou em 2005, quando teve a primeira pesquisa aqui dentro da comunidade. Veio uma professora, uma pesquisadora por nome Ana Felícia, ela veio pesquisar aqui porque ela viu no histórico que existia negro no Amazonas, e a onde ela foi indicada ${ }^{90}$, foi no Andirá. Aí, ela chegou aqui, conversou com o pessoal que foram contando que a gente tinha sangue de negro, porque o nosso princípio tinha vindo da África. Aí, foi que começou a ter o levantamento da procura dos negros né. Aí, chegou à conclusão que hoje nós somos reconhecido. Essa luta foi muito grande, tá sendo até hoje muito grande essa luta ${ }^{91}$.
\end{abstract}

Além das ideias de pertencimento e reivindicação de ancestralidade, as narrativas de Maria Amélia iluminam também para a existência de "agentes externos". Sujeitos, órgãos e instituições que influenciaram nos processos de compreensão de si ao longo do pós-abolição. Refletiram que continuam os "pretos do Matupiri” a serem "escadas para os fazendeiros", reatualizando trajetórias metaforizadas como "escravos do trabalho". Gentes como seu Adelino, que ao rememorar sua trajetória e dos seus irmãos Henrique, Álvaro, Antônio, Gonçalo, Ferro, lembra que "só trabalhavam para os outros, e só para comer. Vivia andando por aí. Chegava no final do mês, só via um quilo de açúcar, uma barra de sabão para lavar a calça" ${ }^{92}$. Suas trajetórias individuais e familiares indicam cenários diversos também visualizado em narrativas como as da liderança Maria Amélia, quando fala sobre sua inserção nessas novas cadeias de dependências no rio Andirá.

\begin{abstract}
Depois de adulta, eu comecei a trabalhar, "formei” a minha família, trabalhei; Criava eles e ainda também fui escrava naquela época! Cansei de plantar de três a cinco hectares de capim nos terrenos, na época de 80, quando os fazendeiros começaram a chegar dentro da área do quilombo... A gente servia de escravo, plantando capim pros fazendeiros. A gente tirava o capim carregava com os nossos próprios braços; com os nossos próprios punhos, para ganhar aquela 'mixaria'; aquela 'mixaria' que não valia uma diária[...].
\end{abstract}

No Maranhão, eu fui em 2013 para um Congresso, fizeram uma pergunta para mim, o seguinte: “-Por que eu era uma pessoa que estava lutando por causa de

\footnotetext{
${ }^{89}$ Idem.

90 A indicação sobre a existência de comunidades negras dada a pesquisadora da Fiocruz foi segundo a mesma, dada na Cidade de Alenquer, quando participava do Encontro "Raízes Negras" promovido pelas associações de comunidades quilombolas dos munícipios de Óbidos, Oriximiná, Santarém, Alenquer e Curuá.

${ }^{91}$ Maria Amélia, agricultora, 55 anos. Entrevista. Outubro de 2015. Santa Tereza do Matupiri.

${ }^{92}$ Adelino Pereira de castro, 89 anos. Entrevista. Maio de 2016. Quilombo Santa Tereza do Matupiri.
} 
pedir as nossas terras de volta; tirar da mão das pessoas estranhas que lá viviam?" Eu disse assim: "-Porque eu, no momento, até agora, não acho que seja certo o meu povo viver servindo de escravo até hoje dentro da nossa comunidade, porque nós temos muitos meios". Aí, eu expliquei que eu penso, assim, antigamente meus avós, meus tios, minhas tias eles tinham guaranazal, eles tinham laranjal, eles tinham cafezal. Hoje o pessoal acabou, porque o pessoal virou diarista; diarista sem valor, porque uma diária - dento da área de quilombo e de não quilombo - é vinte e cinco reais... O que é vinte e cinco reais?. Hoje em dia, $\mathrm{R} \$ 25,00$ (vinte e cinco reais) não é mais nada!. Então, se a gente deixar; se sair todo mundo que quer fazer o povo quilombola de escravo - eles saindo fora de nossas áreas - todo mundo vai plantar, vai criar como criava antigamente, vai voltar àquela vida feliz que a gente tinha, que vendiam a castanha, o cipó, o breu. Eles trabalhavam, antigamente, o mês de janeiro é o tempo que juntavam a castanha: viviam da castanha, viviam da seringa, eles viviam do cipó, eles viviam do tipiti, eles viviam da vassoura. Hoje em dia, trabalham pela diária que não dá o valor da diária de um homem. Eles se "trocaram"; deixaram de fazer o seu próprio trabalho para trabalhar fazendo a vida dos outros. Então, isso é a minha preocupação dentro das minhas comunidades quilombolas; quilombolas, porque eu não falo só por uma comunidade quilombola, eu defendo as cinco comunidades quilombolas, porque todos eles precisam de ter sua libertação! ${ }^{93}$. [Grifos Nossos].

Apesar e além das estratégias constantes de sufocamento das terras produtivas para pastagens e os assédios financeiros das relações pautadas em diárias pagas com dinheiro, classificada pelas lideranças como "mixaria", ocorreram iniciativas que configuram processos sociais e ações resultadas em construções de redes de atuações políticas. Intensamente conectadas à agentes externos, iniciou-se um processo de estruturação da sua luta pelo reconhecimento étnico, social e territorial quilombola. Portanto, a partir de diálogos profundos com “agentes externos” e com contextos nacional e regional de lutas por reconhecimentos dos territórios tradicionalmente ocupados por comunidades ter chegado nas cabeceiras do rio Matupiri, "nós fundamos uma federação pra nós, (...), pra fazer o mapeamento todinho da área. Passamos três meses fazendo isso pra gente adquirir os conhecimentos que as pessoas antigas fizeram pra nós conversando conosco. Depois fizemos o resumo, onde tiramos as partes principais" $" 94$

Houve imediatamente a tentativa, por meio das lideranças comunitárias recém constituídas, de (re)construir uma memória de origem "comum", relacionada ao tempo do cativeiro. Uma "memória como função social”, pautada nas narrativas dos velhos e velhas, que “desempenha uma função para a qual está maduro, a religiosa função de unir

\footnotetext{
93 AMÉLIA, Maria. Trilhas percorridas por uma militante quilombola: vida, luta e resistência. Maria Magela Mafra de Andrade Ranciaro, org.; Alfredo Wagner Berno de Almeida, ed.; Rio de Janeiro: Casa 8, 2016, p.31-32.

94 Maria Cremilda Rodrigues, 59 anos. Técnica de Enfermagem. Bisneta de Benedito Rodrigues da Costa. Liderança do movimento quilombola do Andirá Presidente da Federação Quilombola(2009-2011). Entrevista. Agosto de 2015. Parintins-AM.
} 
o começo ao fim, de tranquilizar as águas revoltas do presente alargando suas margens" ${ }^{\text {95 }}$. Muitos dos quais, tornados os "guardiões das memórias" do passado da escravidão na Amazônia ${ }^{96}$. Suas memórias individuais iluminam processos históricos coletivos de lutas e resistências no Andirá. "Essas histórias coletivas são, inúmeras vezes, marcadas por contradições e conflitos na busca por definição do que ficará registrado para as gerações futuras, trata-se da luta pela construção do reconhecimento"97.

O processo de (re)construção dessa memória no Andirá, partiu de uma dada situação social atual de reivindicantes como grupo étnico, ligado a um passado de cativeiro. Precisaram disso, pois, "não há evocação sem uma inteligência do presente, um homem não sabe o que ele é se não for capaz de sair das determinações atais"98. Tais ações obedeciam aos projetos de identidade encampados pela FOQMB, o que nos remete ao fato de que a "memória é um elemento constituinte do sentimento de identidade, tanto individual como coletiva" ${ }^{99}$. Soma-se a isso, as condições de conflitos locais e necessidades do presente. Essas emergências podem ser também compreendidas como "uma construção da nova identidade quilombola através de filhos e netos, por meio da recuperação das narrativas de seus pais e avós, mas desenvolvendo agora, novas interpretações" ${ }^{100}$. Sobre esse processo de aprendizagem da nova identificação, confessa uma das lideranças “[...] eu nem sabia o que era quilombola!. Sinceramente não vou dizer que eu sabia, que eu sei. Eu não era não interessava nisso não [...]"101.

Para fins de análise das formas e dos processos de conhecimentos mobilizados nos diferentes momentos do MSQA, o apresentamos dividido em quatro frentes básicas, denominadas pelos sujeitos locais como "movimentação", por vezes concomitantes e em muitos casos conflitantes, a saber: I- A primeira movimentação veio das comunidades de São Paulo e Boa Fé, coordenado pelo senhor Efraim Rodrigues. Segundo relatos, este

\footnotetext{
${ }^{95}$ BOSI, Ecléa. Memória e sociedade: Lembranças dos velhos. - 3. ed. - São Paulo: Companhia das Letras, 1994, p.82.

${ }^{96}$ FUNES, A. Eurípedes. Nasci nas Matas, nunca tive senhor. História e memória dos mocambos do Baixo Amazonas. Tese. (doutoramento de História) FFLCH/USP, São Paulo, 1995; ACEVEDO, Rosa ; CASTRO, Edna. Negros do Trombetas: Guardiões das matas e rios. Ed. Cejup/UFPA-NAEA, Belém, 1998, $2^{\mathrm{a}}$ edição. ${ }^{97}$ DELGADO, Lucília de Almeida Neves. Jango: cinema, história, memória e reconhecimento intersecções. In: DELGADO, Lucília de Almeida Neves; FERREIRA, Marieta de Moraes. História do tempo presente (org.) - Rio de Janeiro: Editora FGV,2014, p. 69.

${ }^{98}$ BOSI, Ecléa. Memória e sociedade: Lembranças dos velhos. - 3. ed. - São Paulo: Companhia das Letras, 1994, p.82, p.81

${ }^{99}$ POLLAK, Michael. Memória e Identidade social. Estudos Históricos. Rio de Janeiro, RJ. vol.05, n.10, 1992, p. 2000-2012, p.205

100 MATTOS, Hebe. Cativeiro e Políticas de reparação no Brasil. Revista USP, São Paulo, n.68, dezembro/fevereiro 2005-2006. p.104-111, p.110

${ }^{101}$ Idem.
} 
teve contatos com a União de Negros pela igualdade-UNEGRO/AM, uma vertente do Movimento Negro em Manaus, por meio do Vereador Aderaldo da cidade de Barreirinha; II- A segunda movimentação veio da comunidade Trindade, tendo à frente os irmãos Freitas de Castro(João, Nicanor, Tiniel, Adelson, Luís e Esmeraldina sua Mulher). Tiveram assessoria de um certo Adel da cidade de Barreirinha e acompanhamentos do Filósofo, militante do Partido dos Trabalhadores e Funcionário Público, lotado da Secretaria de Fazenda de Parintins, Antônio Andrade;

III- A terceira movimentação veio da comunidade Santa Tereza do Matupiri. Tem como agente externo, a pesquisadora da Fiocruz Amazônia, Ana Felícia Hurtado Guerreiro, colombiana, professora da Universidade do Estado do Amazonas-UEA, lotada na Escola de Saúde em Manaus. Em 2005 desenvolvia pesquisas sobre saúde de populações negras rurais na Amazônia, com experiência pelo Pará, onde consta que ficou sabendo de quilombolas no rio Andirá e no rio Jaú, em Novo Airão ${ }^{102}$. Teve conhecimento de tais realidades em Alenquer-PA por ocasião do evento de mobilização social e política, realizado pelas associações quilombolas do oeste paraense desde a década de 1980 denominado de "Raízes Negras"103. Destacamos que esta pesquisadora despertou nos moradores os primeiros sentimentos de organização política em torno da busca pelos direitos depositados no artigo constitucional. Orientando-os para organizar suas lutas a partir de uma Federação e não mais associação fechada em uma comunidade apenas, como vinha ocorrendo até então. Sobre a criação da FOQMB, Maria Cremilda Rodrigues dos Santos nos informa desde os primeiros acessos da pesquisadora Ana Felícia que havia ido ao Andirá e precisava de alguém para gerir tal órgão. No caso os parentes do Matupiri buscaram Cremilda que na ocasião trabalhava como técnica de enfermagem em Barreirinha:

[...] - ela deu esse número pra você ligar pra ela. Aí eu peguei e liguei pra dona Lúcia e aí eu liguei pra doutora Ana Felícia também. Ela disse: - Cremilda, eu gostaria que você viesse aqui em Manaus para gente dá uma conversada em relação aos quilombos. Por que eu sei que existe quilombo aí no rio Andirá, no município de Barreirinha, em santa Tereza. Eu estive lá. Daí começou tudo né!. Aí eu fui para Manaus, tinha dois rapazes que iam para lá para a gente participar de um treinamento sobre a pesca né, e eu peguei o embalo deles e me mandei. Chegamos lá, nós nos reunimos eu e essa presidente [Maria Amélia] que é agora. E aí, não tinha quem assumisse logo a presidência. Por que não foi por votação né! Foi apontado o dedo lá na hora. - Olha, nós já queremos começar esse trabalho e nós queremos saber quem de vocês podem ficar como presidente?. - Se não houver muito problema lá dentro da comunidade, eu ficaria, eu disse. Se também se tiver algum problema eu não

102 SIQUEIRA, João. “Tambor dos pretos”: processos sociais e diferenciação étnica no rio Jaú, Amazonas. Tese em Antropologia Social. Uff, Niterói, 2012.

103 AZEVEDO, Idaliana Marinho. Puxirum. Memórias dos negros do Oeste Paraense. Belém:IAP,2002. 
fico não. - Bora Cremilda, a gente coloca você como presidente e depois você vai lá e explica a situação tudinho para o pessoal e aí eu fiquei. Eu entrei em 2009 e saí em 2012, mas eu não concluí meu trabalho! Mas eu consegui alguma coisinha. Já consegui por que nós demos um passo na frente, mais um pouquinho devido essa criação dessa Federação. Essa federação é federação da organização dos quilombolas do município de Barreirinha ${ }^{104}$.

Em 2009, portanto, Maria Cremilda é tornada primeira Presidente da FOQMB. Utilizando-se de suas redes de relações municipais e estaduais, promove inúmeras oportunidades de acessos daquelas comunidades às políticas públicas e programas sociais do governo federal: $\boldsymbol{a}$ ) de combate à fome e a miséria/de alimentação; $\boldsymbol{b}$ ) de casa própria rural; c) de acesso a projetos para levar água potável. Também outros benefícios oferecidos pelo Estado brasileiro, que àquela época, ainda respeitava as conquistas dos movimentos sociais e também compreendia o valor e o significado das políticas de reparação das injustiças sociais construídas historicamente. Nominando os tais benefícios como sendo direitos sociais, buscados desde o início do movimento, alguns dos quais, recebidos mesmo sem terem em mãos suas certidões de auto declaração da FCP. Apesar de ter realizado o primeiro grande "puxirum de memórias", afim de produzir sínteses históricas e iniciar processos de reconhecimentos frente o Estado brasileiro, naquele contexto não se avançou muito, no sentido de conseguir a certidão. "Mas eu não conclui meu trabalho!"105. Inúmeros foram os entraves, como os apontados anteriormente, dadas as relações de poderes locais já denunciadas por Esmeraldina, Maria Amélia e outras "vozes da Mata". Também evidenciadas no relatório antropológico de João Siqueira, quando informa das investidas dos poderes locais no sentido das produções de pressões sobre essas primeiras lideranças e dos parceiros próximos dos quilombolas de Trindade, procurados por fazendeiros do Andirá ${ }^{106}$;

IV- A quarta e mais recente movimentação foi registrada a partir de 2012 e veio do quilombo de Santa Tereza do Matupiri, em conjunto com os demais. Teve como agentes externos sujeitos envolvidos com o PNCSA, por meio da pesquisadora Maria Magela de Andrade Ranciaro que como já informado, desenvolvia pesquisas para compor tese de doutorado junto ao Programa de Antropologia Social PPGAS/UFAM, tendo como objeto de estudo os processos de Territorialização quilombola no rio Andirá. Maria Amélia que já fazia parte da FOQMB como conselheira desde a gestão de Maria

\footnotetext{
${ }^{104}$ Maria Cremilda Rodrigues dos Santos. 59 anos. Entrevista. Agosto de 2015. Parintins-AM. ${ }^{105}$ Maria Cremilda Rodrigues dos Santos. 59 anos. Entrevista. Agosto de 2015. Parintins-AM.

${ }^{106}$ SIQUEIRA, João. Relatório Técnico de Identificação e Delimitação- RTID do território quilombola do rio Andirá, Manaus-Am, 2016.
} 
Cremilda, é eleita "Presidenta da Federação"107. Nesta fase, assumiu a função por dois mandatos(2012-2014 e 2014-2016) ${ }^{108}$. É nesta etapa que os processos para certificação, paralisados junto aos órgãos em Manaus, são retomados a partir de provocações das lideranças locais na pessoa de Maria Amélia e a decisiva mediação dos novos agentes externos. A partir de 2016 torna-se articuladora desse órgão, mantendo vivas as redes construídas ao longo do movimento e produzindo diálogos entre as realidades quilombolas do Amazonas.

As análises dos "arquivos de memórias"109 produzidos sobre essa quarta etapa dão conta da existência de uma agenda mais estruturada, politizada e devidamente etnicizada. O que nos leva a ressaltar as importâncias das novas redes de relações e processos de conhecimento traçados, a partir de então. Registra-se nessa etapa a ocorrência de inúmeros cursos promovidos por esses "agentes externos" junto ao MSQA, que cada vez mais politizava suas ações frente seus antigos opositores e o Estado brasileiro. Tais redes e conexões tornaram-se fundamentais para certificação da FCP como quilombolas em 2013 e, a partir de então, dar entradas e promover os processos iniciais dos pedidos de demarcações do território junto ao INCRA, que já produziu seu Relatório Antropológico $^{110}$. No trecho abaixo, Maria Amélia sintetiza esse processo de lutas pelos reconhecimentos no Andirá, a partir de sua gestão.

Ainda não tinha sido definido em Assembleia a nossa auto definição da remanescência, por isso a Palmares não podia fazer nada. Acho que é essa ata que chegou para lá foi da primeira gestão, do tempo da dona Clemilda, só que como ela não reconheceu em Cartório, ou não fez o levantamento; o cadastro dos moradores dos quilombos, e, por isso, a Palmares também não pode nos

\footnotetext{
${ }^{107}$ Como se apresentava em 2016 durante sua estada na Universidade do Estado do Amazonas - Centro de Estudos Superiores de Parintins. UEA/CESP para promover uma conferência no evento do curso de História.

108 Após 2016, a FOQMB tem como presidente eleito Tarcísio dos Santos Castro(2016-2018; reeleito em 2019 para mais dois anos). Maria Amélia continua como articuladora desse órgão. Suas funções estiveram, dentre outras, em estabelecer e fortalecer as redes com os parceiros externos "almejndo melhorias para os quilombos do Andirá". Também passou a visitar outros quilombos do estado do Amazonas, a fim de compartilhar suas experiências (foi o que fez no quilombo Serpa em Dezembro de 2017, quando pude acompanhá-la por dois dias), suas articulações também estendem-se aos quilombos urbanos de Novo Airão e Barranco de São Benedito. Participa do planejamento para a realização do I Encontro Estadual das Comunidades quilombolas do Amazonas, planejado pelo PNCSA em conjunto com as lideranças quilombolas do estado. Tem representado o Andirá em eventos acadêmicos regionais e locais.

${ }^{109}$ RIOS, Ana Maria; MATTOS, Hebe Maria. Memória do cativeiro: família, trabalho e cidadania no PósAbolição. Rio de Janeiro: Civilização Brasileira, 2005.

${ }^{110}$ A peça do RTID aparece neste texto como uma fonte sobre o MSQA. "A postura metodológica que orientou as diversas fases do trabalho de campo e, especialmente, a coleta de dados e de informações antropológicas, apoiou-se fundamentalmente na etnografia. Ao longo de toda pesquisa de elaboração deste documento realizei seis atividades de campo. A primeira ocorreu entre os dias 11 e 15 de novembro de 2013; a segunda foi realizada de 16 a 25 de setembro de 2014; a terceira de 09 a 17 de junho de 2015; a quarta foi realizada no período de 11 a 20 de agosto de 2015; a quinta de 16 a 21 de novembro de 2015; e a sexta de 21 a 26 de julho de 2016"(SIQUEIRA, 2016,p.7).
} 
ajudar. Então, aconteceu assim, a gente teve a oportunidade de conhecer, através do Clóvis, a Cartografia Social da Amazônia, onde o professor Alfredo Wagner é o Coordenador de lá. Fomos para saber como a Cartografia poderia nos ajudar lá dentro dos quilombos. Conhecemos o Professor Emmanuel Farias Júnior, conhecemos a professora Magela Andrade, conhecemos a Carol [Carolina Silva] que explicaram sobre o trabalho deles. Voltei pra Comunidade de Santa Tereza do Matupiri e, quando foi no dia 11 de janeiro de 2013, realizamos uma Assembleia que aprovou o Ofício de pedido nosso pra ser realizada a Oficina de Mapeamento do nosso território e do Curso de GPS. Aí, tá... Levamos pra Cartografia esse nosso pedido e quando foi no dia 14 até o dia 19 de fevereiro de 2013 foi acontecendo esses dois trabalhos, com a presença de mais de sessenta pessoas de todas as cinco comunidades, onde compartilharam essas pessoas da Cartografia junto com a gente[...]. Depois de tudo isso... Aí, quando nós terminamos com o nosso trabalho, eu vim correndo para Manaus, cheguei lá em Manaus e procurei a professora Magela e o professor Emmanuel para saber onde eles poderiam nos ajudar de novo. Foi aí que eles explicaram que a gente tinha que reconhecer aquelas atas como nós sendo da remanescência de quilombo. E ainda temos uma história, onde para gente reconhecer essas atas, nós atravessamos a Eduardo Ribeiro correndo porque o cartório já estava fechando, para ver se conseguia mandar esse documento no mesmo malote da cartografia para Brasília [...]. E veio a convenção, melhor dizendo, o Curso que falava sobre Convenção 169 [OIT]. A Cartografia me mandou para dentro de novo das comunidades quilombolas essa Convenção 169, e quando foi no de 26 a 30 de setembro de 2013 que aconteceu esse Curso, que foi todo orientado pela Dra. Sheilla Dourado, ela é advogada, do Direito Ambiental [...]. Isso foi para nós sabermos os nossos direitos; saber qual o valor que nós remanescentes de quilombos temos. Um pouquinho depois do Curso da Convenção 169, isto já em outubro de 2013, chegou as Certidões de Reconhecimento, em nossa mão, da Palmares já entregando [...]. E ainda tem isso, em novembro quando chegou o resultado nós fomos até o INCRA. Quando eu cheguei em Barreirinha, indo de Manaus para Barreirinha, no dia que eu cheguei o Correio foi levar na minha casa as Certidões originais. No Ofício é da data de 31 de outubro de 2013 e tem a assinatura do diretor que é o seu Alexandre Reis e nas Certidões é do Presidente da Palmares, José Hilton Santos de Almeida, aquele que assinou todas elas ${ }^{111}$.

O relatório sobre o território está pronto e já foi publicado, no entanto, as dinâmicas políticas da República brasileira, mudaram outra vez. E as velhas forças políticas sentem-se à vontade para não realizar políticas de reparação das injustiças históricas, como as que preveem o artigo 68/ADCT C.F de 1988, ainda mais se isso passar pela questão da terra, sempre um grande problema no Brasil. Pelo contrário, ressuscitam projetos que tentam frear as conquistas, entregam as demandas do campo à bancada ruralista e do agronegócio, que produz alimentos para o mundo e (des)esperanças para povos e comunidades tradicionais. Enquanto aguardam pela titulação do território, o MSQA se dispersa e perde um pouco a força, os opositores articulam-se outra vez, interferindo naquela dispersão. Os agentes externos, por terem outras comunidades para auxiliar, alargam os espaços de idas ao Andirá.

111 AMÉLIA, Maria. Trilhas percorridas por uma militante quilombola: vida, luta e resistência. Maria Magela Mafra de Andrade Ranciaro, org.; Alfredo Wagner Berno de Almeida, ed.; Rio de Janeiro: Casa 8, 2016, p.57-58. 
Sem tais redes de relações entre o local e os agentes externos, os movimentos sociais na Amazônia ficam mais frágeis. No caso específico, o MSQA perde maiores capacidades de resistências, ficando as lideranças isoladas em suas ações políticas. Ações que podem, e continuamente o foram sufocadas pelas investidas dos poderes locais, dialogados com os cenários nacionais atuais que lhes concede acenos e permissividades para promover mortes no campo, outra vez ${ }^{112}$. Isto ganha relevo em cenários por qual passa a política brasileira, onde os representantes das chamadas agro estratégias parece sentirem-se à vontade em suas velhas ações e discursos. Objetivam-se em práticas de violência no campo, como as já denunciadas por Esmeraldina, antes "da certidão da Palmares"113. Também, as que vemos assistindo sobre mortes de lideranças de movimentos sociais em estados amazônicos como Maranhão e Pará, conforme informativos da Pastoral da Terra, entidade ligada à Igreja Católica.

O Estado do Amazonas em suas fronteiras leste(onde fica o rio Andirá) e Sul está mais exposto a esse tipo de conflito, sendo especulado continuamente desde as últimas décadas do século XX pelos agentes das agro estratégias. Em 2018, a principal voz do Andirá foi abertamente ameaçada, mas logo procedeu a divulgação das ameaças entre os meios de comunicação em Parintins e amplificados pelos agentes e redes de solidariedades externas aos "mandões" do Andirá ${ }^{114}$. Isto ganha relevo, especialmente em contextos onde se retiram os agentes externos que foram amplificadores das "Vozes da Mata". No entanto, aqueles cenários de direitos constitucionais, aos quais nos referimos nas sessões anteriores passaram por questionamentos nos tribunais superiores do país. Nos referimos a Ação Direta de Inconstitucionalidade-ADI, impetrada no Supremos Tribunal Federal-STF, questionando o artigo 68/ADCT e suas atribuições quanto a demarcação das terras quilombolas. Após seguidas anulações(agostos, e novembro de 2017), o julgamento ocorreu em 8 de fevereiro de 2018 e a ADI 3239 foi finalmente

\footnotetext{
${ }^{112}$ Conforme relatórios da comissão pastoral da terra, aumentou as mortes por conflitos no campo em todo o país. Ver "relatório dos conflitos no campo no Brasil 2017". https://www.cptnacional.org.br/lojavirtual/conflitos-no-campo/4372-conflitos-no-campo-brasil-2017. Acesado em 28/09/2017.

${ }^{113}$ Para uma compreensão aprofundada das ações das agro-estratégias na Amazônia ver SILVA, Marilene Corrêa. Agroindustria. In: Metamorfoses da Amazônia.2 edição. Manaus: Editora Valer, 2013, p.135-176. ${ }^{114}$ Ressaltamos as denúncias feitas em maio de 2018 por Maria Amélia dos Santos Castro, aos órgãos de impressa de Parintins e depois no Ministério Público Federal-MPF em Manaus, acerca das ameaças sofridas por discursos de fazendeiros do Andirá. A dimensão tomada pela denúncia indica para os canais e redes de relações de solidariedades e visibilidades alcançados pelo MSQA, que aprendeu "que as coisas não se resolvem em Barreirinha!". Ver "Oi Siricoté: os quilombolas de Barreirinha”, crônica publicada no blog de José Ribamar Bessa Freire "taquiprati.com.br" em 8 de maio de 2018. http://taquiprati.com.br/cronica/1394-oi-siricote-os-quilombolas-de-barreirinha. Acesso em 09 de maio de 2018.
} 
rejeitada por 10 votos a 1. Em fevereiro de 2019 teve seu acordum publicado, declarando, enfim, a constitucionalidade do artigo 68 e dos procedimentos aferido no decreto $4.887 / 2003$.

No movimento de luta pelo reconhecimento o "tradicional" como operativo foi aparentemente deslocado no discurso oficial, afastando-se do passado e tornando-se cada vez mais próximo de demandas do presente dessas comunidades que demandam o Estado brasileiro. Em tais percursos:

(...) o fator identitário e todos os outros fatores a ele subjacentes, que levam as pessoas a se agruparem sob uma mesma expressão coletiva, a declararem seu pertencimento a um povo ou a um grupo, a afirmarem uma territorialidade específica e a encaminharem organizadamente demandas face ao Estado, exigindo o reconhecimento de suas formas intrínsecas de acesso à terra $(. . .)^{115}$

Tais indicativos nos ajudam a compreender como o MSQA, esteve ligado aos processos externos àquele rio, e como isto lhes deu devidos suportes para a construção da nova identificação étnica e territorialidades quilombolas. Foram devidamente orientados por tais motivações étnicas no sentido de construção de memórias sobre si, apontando para as origens, para as relações com os territórios tradicionalmente ocupados e para as relações de sentidos produzidas nessas interações sociais entre os grupos que “espalharam-se pelo Andirá", mas que se requalificam como grupo étnico para mostrarse ao Estado brasileiro. Esse fenômeno não está referido apenas ao Andirá, mas há outras realidades brasileiras que são marcadas por tais impasses e construções de identidades, pautadas nos fatores étnicos, a partir de onde, os sujeitos assumem novas configurações sociais. São portanto, processos sociais "que têm em comum o princípio de que a identidade étnica implica uma série de restrições quanto aos tipos de papéis que um indivíduo pode assumir, e quanto aos parceiros que ele pode escolher para cada tipo diferente de transação"116.

Sobre esse processo de produção das condições sociais para afirmação da nova pertença étnica, Maria Amélia é categórica ao falar acerca dos resultados das muitas mobilizações por ela coordenadas no curso do MSQA, o que lhes conferiu "personalidades sociais""117. A partir de suas condições contemporâneas, Amélia e os seus

\footnotetext{
115 ALMEIDA, Alfredo Wagner Berno de. Terra de quilombo, terras indígenas, "babaçuais livre”, “castanhais do povo", faixinais e fundos de pasto: terras tradicionalmente ocupadas. - 2. a ed, Manaus: PGSCA - Ufam, 2008, p.29-30.

${ }^{116}$ BARTH, Friedrik. Os Grupos Étnicos e Suas Fronteiras. In: O Guru, O Iniciador e Outras variações Antropológicas. Rio de Janeiro: Contra Capa, 2000, p.16.

${ }^{117}$ Idem
} 
também (re)construíram memórias que os ligam com uma ancestralidade africana relacionada aos mundos do trabalho na Amazônia. Tendo que positivar suas memórias, etnicizá-las e politizá-las para configurar as lutas em favor de seu grupo social que no âmbito do movimento, constitui-se como grupo étnico. Indagados sobre os significados da nova identificação como quilombolas, são taxativos em acreditar nas melhoras advinda com as novas "personalidades sociais", reconhecidos como quilombolas do Andirá:

\begin{abstract}
Hoje a vida vai ser diferente né!. Hoje já está sendo, já estamos de olho aberto. Não é mais aquele olho fechado que antigamente existia. Então para a gente o nosso reconhecimento foi verdadeiramente uma pátria muita alegre, muito boa. É uma honra muito grande, porque nós temos agora outros valores diferentes!. Vamos ser tratado diferente como era no princípio. Se no princípio nossos pais, nossos avós não foram escravos de senzala. Foram escravos do trabalho, que si haviam aqui de servir, de escada para os fazendeiros, para as pessoas que vinha vender mercadoria, os que regatiavam por aqui, eles se matavam tirando madeira pra troca com rancho ${ }^{118}$ [Grifos nossos]
\end{abstract}

A assertiva dessa liderança quilombolas de que a partir de "hoje a vida vai ser diferente!", parece dialogar com o fato de que a Identidade étnica "é uma identidade imperativa" ${ }^{119}$, na medida em que, aponta cenários de existências para quem a assume. $\mathrm{O}$ processo de construção dessa memória do cativeiro no Andirá partiu de uma dada situação social atual de reivindicantes como novo grupo étnico. A partir de então, passou a ligarse politicamente por meio da memória, àquele passado das relações de trabalho na Amazônia. Percebemos as intenções das lideranças recém constituídas em (re)configurar seu território atual. O fazem por meio de uma memória de origem comum, relacionada ao cativeiro, pautada nas narrativas dos mais velhos. "Um mundo social que possui uma riqueza e uma diversidade que não conhecemos pode chegar-nos pelas memórias dos velhos" ${ }^{120}$. Esses sujeitos foram tornados, então, as fontes privilegiadas do projeto de recuperação de aspectos da história social do grupo.

\title{
Considerações Finais
}

Ocorre que em seus percursos por reconhecimento perante o Estado brasileiro, os quilombolas do Andirá potencializam sua luta, por meio da recuperação das narrativas de seus pais, avós e bisavós. Para as quais, desenvolvem novas interpretações, à luz dos anseios contemporâneos. Sobre os caminhos e resultados desses processos de lutas dos

\footnotetext{
${ }^{118}$ Maria Amélia dos Santos Castro. 55 anos. Entrevista. Outubro de 2015. Quilombo Santa Tereza. ${ }^{119}$ BARTH, Friedrik. Os Grupos Étnicos e Suas Fronteiras. In: O Guru, O Iniciador e Outras variações Antropológicas. Rio de Janeiro: Contra Capa, 2000, p.17.

${ }^{120}$ BOSI, Ecléa. Memória e sociedade: Lembranças dos velhos. - 3. ed. - São Paulo: Companhia das Letras, 1994, p 82.
} 
"novos quilombos", para os quais a identificação coletiva é processo, construção e só pode ser entendida levando em conta contextos históricos e políticos ${ }^{121}$. A exemplo do protagonizado pelas vozes do Andirá, da qual Maria Amélia tornou-se um caso emblemático.

Descrever aspectos dos caminhos de lutas do Andirá torna-se um ato de inteligibilidade, solidariedade e responsabilidade para com as demais realidades amazônicas que tentam romper os silêncios da cor, para os quais foram colocadas. Também reflete uma necessidade da história do tempo presente, onde (re)pensar os passados e as existências presentes se torna, cada vez mais, um ofício fundamental.

Data de submissão: $31 / 10 / 2019$

Data de aceite: 04/04/2020

121 MATTOS, H. Cativeiro e Políticas de reparação no Brasil. Revista USP, São Paulo, n.68, dezembro/fevereiro 2005-2006. p.1 


\section{Referências Bibliográficas}

ABREU, Marta; DANTAS, Carolina Vianna; MATTOS, Hebe (ORGs). Histórias do pós-abolição no mundo atlântico: identidades e projetos políticos - volume 1/ organizado por Martha Abreu, Carolina Vianna Dantas e Hebe Mattos. - Niterói: Editora da UFF, 2014.

ABREU, Marta; DANTAS, Carolina Vianna; MATTOS, Hebe (ORGs). Histórias do pós-abolição no mundo atlântico: identidades e projetos políticos - volume 2 / organizado por Martha Abreu, Carolina Vianna Dantas e Hebe Mattos. - Niterói: Editora da UFF, 2014.

ABREU, Marta; DANTAS, Carolina Vianna; MATTOS, Hebe (ORGs). Histórias do pós-abolição no mundo atlântico: identidades e projetos políticos - volume 3 / organizado por - Niterói: Editora da UFF, 2014.

ALBERT, Verena. Histórias dentro da História. In: PINSK, Carla Bassanezi. Fontes Históricas. 3 ed. - São Paulo: Contexto, 2011, p.171

ALMEIDA, Alfredo Wagner Berno de. Agroestratégias de desterritorialização: os direitos territoriais e étnicos na mira dos estrategistas dos agronegócios. In. RODRIGUEZ, José Ezequiel Basani Et Ali (Orgs). Povos tradicionais, fronteiras e geopolítica na América Latina: uma proposta para a Amazônia - Manaus: Edua, 2014.

ALMEIDA, Alfredo Wagner Berno de. Prefácio da primeira edição. In: ACEVEDO, Rosa ; CASTRO, Edna. Negros do Trombetas: Guardiões das matas e rios. Ed. Cejup/UFPA-NAEA, Belém, 1998, $2^{a}$ edição.

ALMEIDA, Alfredo Wagner Berno de. Terra de quilombo, terras indígenas, "babaçuais livre", "castanhais do povo", faxinais e fundos de pasto: terras tradicionalmente ocupadas. - 2. ${ }^{\mathrm{a}}$ ed, Manaus: PGSCA - Ufam, 2008.

ALMEIDA, Alfredo Wagner Berno de. Territórios e territorialidades específicas na Amazônia: entre a "proteção" e o "protecionismo". Caderno CRH, Salvador, v. 25, n. 64, Jan/Abr. 2012.

AMÉLIA, Maria. Trilhas percorridas por um militante quilombola: vida, luta e resistência. Maria Magela Mafra de Andrade Ranciaro, org.; Alfredo Wagner Berno de Almeida, ed.; Rio de Janeiro: Casa 8, 2016.

ANTONACCI, Maria Antonieta. Memórias ancoradas em corpos negros. São Paulo: Edusc, 2013.

ARRUTI, José Maurício Andion. A emergência dos "remanescentes": notas para o diálogo entre indígenas e quilombolas. MANA 3(2):7-38, 1997.

AVILA, Cristian Pio. Os Argonautas do Baixo Amazonas. Tese. Antropologia Social. Ufam, Manaus-AM, 2016.

AZEVEDO, Idaliana Marinho. Puxirum. Memórias dos negros do Oeste Paraense. Belém:IAP,2002. 
BARTH, Friedrik. Etnicidade e o conceito de cultura. Antropolítica, n. 19. Niterói: UFF, 2005.

BARTH, Friedrik. Os Grupos Étnicos e Suas Fronteiras. In: O Guru, O Iniciador e Outras variações Antropológicas. Rio de Janeiro: Contra Capa, 2000.

BEZERRA NETO, José Maia Escravidão negra na Amazônia (sécs. XVII-XIX). Belém: Paka-Tatu, 2001.

BOSI, Ecléa. Memória e sociedade: Lembranças dos velhos. - 3. ed. - São Paulo: Companhia das Letras, 1994.

BRANDÃO, André; DALT, Salete da; GOUVEIA, Victor Hugo. Comunidades quilombolas no Brasil: características socioeconômicas, processos de etnogênese e políticas sociais. Niterói: EDUFF, 2010.

BURKE, Peter. A história dos acontecimentos e o renascimento da narrativa. In: BURKE, Peter (Org.). A escrita da História. Novas perspectivas. Tradução de Magda Lopes. São Paulo: Editora Unesp, 2011, p. 25.

CAMPOS, Pe. Manuel do Carmo. A decadência do catolicismo popular na região parintinense (1955-1975). Revista de Cultura Teológica. 1995.

CASTRO, Hebe. História Social. 1997. In: CARDOSO, Ciro Flamarion; VAINFAS, Ronaldo (orgs). Domínios da história: ensaios de teorias e metodologias. Rio de Janeiro: Campus, 1997.

DELGADO, Lucília de Almeida Neves. Jango: cinema, história, memória e reconhecimento - intersecções. In: DELGADO, Lucília de Almeida Neves; FERREIRA, Marieta de Moraes. História do tempo presente (org.) - Rio de Janeiro: Editora FGV,2014.

DOMINGUES, Petrônio. Movimento Negro Brasileiro: alguns apontamentos históricos. Movimento negro brasileiro: alguns apontamentos históricos. Tempo [on line]. 2007, vol.12, n.23.

FENELON, Déa Ribeiro. Cultura e História Social: Historiografia e pesquisa. Proj. História, São Paulo, (10), dez. 1993.

FUNES, A. Eurípedes. Nasci nas Matas, nunca tive senhor. História e memória dos mocambos do Baixo Amazonas. Tese. (doutoramento de História) FFLCH/USP, São Paulo, 1995; ACEVEDO, Rosa ; CASTRO, Edna. Negros do Trombetas: Guardiões das matas e rios. Ed. Cejup/UFPA-NAEA, Belém, 1998, $2^{a}$ edição.

GOMES, Ângela de Castro. A guardiã da memória. Acervo - Revista do Arquivo Nacional, Rio de Janeiro, v.9, nº 1/2, jan./dez. 1996.

GOMES, Flávio do Santos. A Hidra e os Pântanos: quilombos e mocambos no Brasil (sécs. XIII e XIX). Tese (Doutorado em História) - UNICAMP/SP, 1997.

GOMES, Flávio do Santos. Mocambos e quilombos: uma história do campesinato negro no Brasil. $1^{\text {a }}$ ed. São Paulo: Claro Enigma, 2015. 
HALL, Stuart. A Identidade cultural na pós-modernidade. Tradução Tomaz da Silva, Guaciara Lopes Louro - 11. Ed.- RJ:DP\&A, 2006.

HAMPANTÊ BÂ, Amadou. Tradição Viva. In: ZERBO, Joseph Ki (org.). História geral da África, I: Metodologia e pré-história da África. 2.ed. rev. Brasília: UNESCO, 2010.

LEITE, Ilka Boventura. Os quilombos no Brasil: questões conceituais e normativas. Etnográfica, Vol. IV (2), 2000.

MATTOS, Hebe. Cativeiro e Políticas de reparação no Brasil. Revista USP, São Paulo, n.68, dezembro/fevereiro 2005-2006.

MONTEIRO, John Manuel. Apresentação. In: ARRUTI, José Maurício. Mocambo. Antropologia e História do processo de formação quilombola - Bauru, SP:EDUSC,2006.

O'DWYER, Eliane Cantarino. Os quilombos e as fronteiras da antropologia. Antropolítica. Niterói, n. 19, 2005.

POLLAK, Michael. Memória e Identidade social. Estudos Históricos. Rio de Janeiro, RJ. vol.05, n.10, 1992, p. 2000-2012.

RANCIARO, Maria Magela de Andrade. "Os cadeados não se abriram de primeira": processos de construção identitária e a configuração do território de comunidades quilombolas do Andirá. Tese em Antropologia Social. Universidade Federal do Amazonas- UFAM. Manaus. 2016.

REIS, Arthur César Ferreira. As Origens de Parintins. Editado pelo governo do Estado do Amazonas. Secretaria de imprensa e divulgação. Palácio Rio Negro, ManausAmazonas, 1967.

REIS, Arthur César Ferreira. História do Amazonas. Belo Horizonte, Manaus: Superintendência cultural do Amazonas, 1989.

RIOS, Ana Maria; MATTOS, Hebe Maria. Memória do cativeiro: família, trabalho e cidadania no Pós-Abolição. Rio de Janeiro: Civilização Brasileira, 2005.

RIOS, Ana Maria; MATTOS, Hebe Maria. O Pós-abolição como problema histórico: balanços e perspectivas. Topoi, V.5, 8, Jan. 2004.

ROCHA, João Marinho da. Das Sementes aos Troncos: História e Memória do movimento quilombola do Rio Andirá. Tese de Doutorado em Sociedade e Cultura na Amazônia. Universidade Federal do Amazonas- UFAM. Manaus 2019.

SALLES, Vicente. O negro na sociedade Paraense. Textos reunidos. Belém: Paka-Tatu, 2004.

SALLES, Vicente. O negro no Pará sob o regime de Escravidão. Ed. Ufpa,1971.

SALLES, Vicente. Os mocambeiros e outros ensaios. - Belém: IAP, 2013. 
SAMPAIO, Patrícia M. Espelhos partidos: etnia, legislação e desigualdade na Colônia. - Manaus: EDUA, 2012.

SAMPAIO, Patrícia M.(Org.). O fim do silêncio - presença negra na Amazônia. Belém: Açaí/CNPq, 2011.298p.

SILVA, Anaíza Vergolino e. Alguns elementos para o estudo do negro na Amazônia. Universidade Federal do Pará. Publicações avulsas nº 8, Museu Paraense Emílio Goeldi, Belém-Pará- Brasil, 1968.

SIQUEIRA, João. "Tambor dos pretos": processos sociais e diferenciação étnica no rio Jaú, Amazonas. Tese em Antropologia Social. Uff, Niterói, 2012.

SIQUEIRA, João. Relatório Técnico de Identificação e Delimitação- RTID do território quilombola do rio Andirá, Manaus, 2016.

SOUZA, Cónego Francisco Bernardino de. Lembranças e curiosidades do Valle do Amazonas. Pará: Tvp do futuro, 1878.

VERGOLINO - HENRY, Anaíza; FIGUEIREDO, Arthur Napoleão. A presença Africana na Amazônia Colonial: Uma notícia histórica. - Belém, Arquivo Público do Pará, 1990. 